\title{
DIALOG ANTAR UMAT BERAGAMA
}

\author{
Oleh: \\ Zainol Hasan \\ Universitas Ibrahimy Ibrahimy \\ hasansideas02@gmail.com
}

\begin{abstract}
:
The past event is book and history. Both of them are not only scary stories not only for mourned but also for a changing reference. Actulally, this earth is not possible to be transformed quickly, but it can be changed depend on the human's sprite to determine wheater it is to dezided to be misereble or properity. A conflict between horisontal contardiction and socity should be stop. The human needs peace of life and not disaster. As the result, all of conflick mus be end of, whatever that are elements, such as the conflick between religion and the other one. In addition, a history has already recorded that the distiction of religions have created a lot of problems and victims. It is terrible and irony that the existence of a religion must be a tool and place to peace and safe. However, in this condition is contraray that a religion is being tool to execute each others. Ther are many nation child to be victims and even they are dead without no rasons. This case must be stop. The gate of pluralism is to find Kalimatun Sawa', a dialuge is to solve relegions problems . In this arena, conflict can be recovered.
\end{abstract}

Keywords: Human, Religion and Dialogue

\section{A. Pendahuluan}

Indonesia sebagai bangsa yang religius, isu agama menjadi sorotan penting dalam ranah kehidupan keberagaman. ${ }^{1}$ Melekatkan agama sebagai satu varian potensial pemicu kekerasan adalah hal yang tidak bijaksana. Karena agama adalah sebuah ajaran yang selalu diasosiasikan dengan ajaran penuh dengan nilai kedamaian dan keselamatan. Sementara dalam satu tindak kekerasan terdapat hal-hal yang dapat menimbulkan kerusakan, kehancuran bahkan kematian. Tindak kekerasan yang mengatasnamakan agama seringkali diterjemahkan oleh sebagian orang sebagai legal doctrine yang harus dilaksanakan. Kekerasan atas nama agama tidak terbatas pada personal semata, melainkan juga menimpa

${ }^{1}$ Hasan Basri Marwah \& Very Verdiansyah, Islam dan Barat : Membangun Teologi Dialog, (Jakarta : LISP Lembaga Studi Islam Progresif Bekerjasama dengan Yayasan TIFA, 2004), hlm. 141. 
terhadap kelompok pemeluk agama lain. Jangkauan tindak kekerasan atas nama agama dapat disaksikan pada hampir semua kawasan di dunia, misalnya; di India, Irlandia, Yerusalem, Filipina, Irak, Nigeria dan juga di Indonesia. ${ }^{2}$ Di Indonesia ketegangan dan kerusuhan yang disebabkan oleh sentimen keagamaan di beberapa daerah, mislanya, di Tasikmalaya, Ketapang, Kupang, Ambon, Poso, Maluku, Situbondo yang mengakibatkan hancurnya tempat-tempat ibadah seperti masjid, mushalla, gereja dan lain sebagainya. ${ }^{3}$

Pluralisme merupakan fakta yang ada disekeliling kita, menolak pluralisme sama halnya menolak kenyataan adanya perbedaan-perbedaan pandangan dan keyakinan dalam masyarakat, ${ }^{4}$ pluralisme bisa menyangkut keyakinan apa saja, dari yang amat sederhana sampai pada yang mendasar, dan pada pelbagai macam level. Perbedaan-perbedaan ini tentu saja menimbulkan gejolak yang sedikit banyak menggoncangkan stabilitas sosial. ${ }^{5}$ Dalam pergaulan dewasa ini, semakin hari semakin

2 Thoha Hamim, Resolusi Konfliik Islam Indonesia, (Surabaya : Lembaga Studi Agama dan Sosial (LSAS) dan IAIN Sunan Ampel, 2007), hlm. 51-52.

${ }^{3}$ Untuk lebihnya jelasnya lih. Sudarto, Konflik Islam Kristen, (Semarang : Pustaka Rizki Putra, 2001), hlm. 11.

4 Tentunya pluralisme merupakan sebuah fenomena yang tidak mungkin dihindari. Manusia hidup dalam pluralisme dan merupakan bagian dari pluralisme itu sendiri, baik secara pasif maupun aktif, tak terkecuali dalam hal keagamaan. Pluralisme keagamaan merupakan tantangan khusus yang dihadapi agama-agama dunia dewasa ini. Sebagaimana menurut Coward, setiap agama muncul dalam lingkungan yang plural ditinjau dari sudut agama dan membentuk dirinya sebagai tanggapan terhadap pluralisme tersebut. Jika tidak dipahami secara benar dan arif oleh pemeluk agama, pluralisme agama akan menimbulkan dampak, tidak hanya berupa konflik antar umat beragama, tetapi juga konflik sosial dan disintegrasi bangsa. Lih. Harold Coward, Pluralisme dan Tantangan Agama-agama (Yogyakarta: Kanisius: 1989), hlm. 167. Bahkan menurut Tracy, diantara agama-agama yang ada di dunia ini tidak ada yang memiliki esensi tunggal, tidak ada muatan tunggal tentang pencerahan atau wahyu, tidak ada cara tunggal tentang emansipasi atau liberasi yang dibangun dalam semua pluralitas itu. Ada perbedaan penafsiran tentang Tuhan itu sendiri; God, Emptiness, Suchness, the One, Nature, the Many. Ada perbedaan pemahaman mengenai apa yang diwahyukan oleh Tuhan tentang Tuhan dan tentang diri kita dalam hubungan kita, tentang harmoni dan disharmoni dengan Tuhan tersebut. Ada perbedaan penafsiran tentang cara apa yang harus kita ikuti untuk mengubah (pandangan kita) dari pemusatan diri secara fatal menuju pemusatan kepada Tuhan secara bebas. Tetapi diskurus dan cara-cara agama seperti itu kadang-kadang bisa saling melengkapi, dan pada batas tertentu, melengkapi beberapa aspek yang belum maju dari yang lain, tetapi pada saat yang sama juga bisa saling mengganggu dan melenyapkan. Lih. David Tracy, Plurality and Ambiguity, Hermeneutic, Religion, Hope (University of Chicago Press, 1987), hlm. 89-90.

5 Syafa'atun Elmirzanah, Pluralisme Konflik dan Perdamaian : Studi Bersama antar Iman, (Yogyakarta : Pustaka belajar, 2002), hlm. 121. 
merasakan intensnya pertemuan agama-agama. Pada tingkah pribadi, hubungan antar tokoh agama di Indonesia, kita melihatnya semakin akrab. Penuh toleransi, dengan keterlibatan yang sungguh-sungguh dalam usaha memecahkan persoalan-persoalan hubungan antar umat beragama yang ada di masyarakat.

Tetapi pada tingkat teologis yang merupakan dasar dari agama itu muncul kebingungan-kebingungan, khususnya menyangkut bagaimana kita harus mendefinisikan diri ditengah agama-agama lain yang juga eksis dan punya keabsahan yang tidak jarang menimbulkan malapetaka. ${ }^{6}$ Maka berangkat dari sinilah penulis menawarkan solusi, yaitu melalui dialog antar umat beragama. Bahkan, Hans Kung seorang teolog Kristen Katolik menegaskan, jika bangsa-bangsa dunia mampu menghadapi dan meyelesaikan krisis yang mengancam manusia sekarang, mereka harus setuju (dalam teori dan praksis) apa yang dikatan dengan etika global. Kesepakatan tersebut tidak dapat dicapai kecuali jika agama-agama dunia bekerjasama, seperti yang dikatakan, "there can be no peace, unity, dialogue among the nation unless there is peace, unity, dialogue among religions", (tidak akan ada perdamaian, kesatuan dan dialog diantara bangsa-bangsa tanpa adanya perdamaian, kesatuan dan dialog antar agama). ${ }^{7}$

\section{B. Makna dan Tujuan Dialog}

Secara etimologis dialog berarti percakapan atau diskusi antar orang-orang yang berbeda pendapat. Dialog berarti "dialeghe" yaitu sedang berbicara, berdiskusi dan beralasan mengenai seluruh aspek persoalan. Maka terjadi kondisi saling mengoreksi menyelesaikan suatu permasalahan baru. ${ }^{8}$ Secara terminologis dialog adalah komunikasi dua arah antar orang-orang yang berbeda pandangan mengenai suatu subjek dengan tujuan untuk memahami secara lebih baik kebenaran subjek lain. Selain itu, dialog juga dapat didefinisikan sebagai pertukaran ide yang diformulasikan dengan cara yang berbeda-beda. ${ }^{9}$

Dialog merupakan pertukaran timbal balik dari pandanganpandangan antara orang-orang yang telah memiliki satu kepedulian murni

\footnotetext{
${ }^{6}$ Budhy Munawar Rahaman, Islams Pluralis : Wacaca Kesetaraan Kaum Beriman, (Jakarta : PT Raja Grafindo Persada, 2004), hlm. 41.

7 Ibid, hlm. 121-122.

8 A. Mukti Ali, dkk., Agama dalam Pergumulan Masyarakat Dunia (Yogyakarta: Tiara wacana: 1997), hlm. 7.

9 Josef Van Ess, "Islam dan Barat dalam Dialog", dalam Nurcholish Madjid, dkk., Agama dan Dialog Antarperadaban (Jakarta: Paramadina, 1996), hlm. 170.
} 
terhadap satu sama lain dan mereka yang terbuka untuk belajar satu sama lainnya. Kecenderungan dialog itu sesungguhnya tidak berhenti hanya sebagai suatu gaya hidup (life-style), tetapi juga dipikirkan untuk menjadi suatu pandangan hidup (way of life). ${ }^{10}$ Oleh karena itu dalam ranah politik, dialog berarti proses demokrasi. ${ }^{11}$

Dari berbagai pengertian tersebut, dapat dikatakan bahwa dialog antar umat beragama adalah pertemuan hati dan pikiran antar pemeluk berbagai agama, komunikasi antara orang-orang yang percaya pada agama sebagai jalan bersama untuk mencapai kebenaran dan kerjasama menyangkut kepentingan bersama. ${ }^{12}$

Dialog sebagai wahana refleksi bersama yang mempunyai daya kritis, baik bagi dimensi praktis maupun refleksi, baik dalam hidup keagamaan pribadi maupun kelompok. Dengan semangat mencari kebenaran terus menerus. Dialog antar agama mempunyai fungsi kritis ke dalam (ad intra) dan ke luar (ad extra). ${ }^{13}$ Dialog pada prinsipnya bertujuan pada penciptaan kerukunan, pembinaan toleransi, kesejahteraan bersama, membudayakan keterbukaan, mengembangkan rasa saling menghormati, saling mengerti, membina integrasi, berkoeksistensi diantara penganut pelbagai agama dan sebagainya. Selain itu, dialog bisa mencapai tujuan yang lebih penting dari ko-eksistensi, yaitu pro-eksistensi. Dalam koeksistensi dialog hanya mengutamakan terciptanya toleransi sebagai satusatunya tujuan. Pro-eksistensi lebih dari sekedar toleransi, yaitu selain mencari dan mengumpulkan segala persamaan doktriner, tradisi, semangat dan sejarah, juga berupaya mencari unsur-unsur yang meliputi perbedaan, bahkan yang menyimpan konflik pun harus dinyatakan. ${ }^{14}$

\section{Materi Dialog}

\section{Dialog teologis}

Pada tingkat teologis antar agama berbicara seputar masalah ketuhanan, masalah kenabian, asal-usul manusia, akar sejarah agama-

\footnotetext{
10 Ahmad Gaus AF dan Komaruddin Hidayat (ed), Pengantar Editor, dalam Passing Over: Melintasi Batas Agama, (Jakarta: Gramedia dan Paramadina, 1998), hlm. 13.

11 Th. Sumartana, "Pluralisme, Konflik dan Dialog: Refleksi Tentang Hubungan Antaragama di Indonesia", dalam Th. Sumartana dkk, Pluralisme, Konflik dan Pendidikan Agama (Yogyakarta: Pustaka Pelajar, 2001), hlm. 87.

12 Herman Leonard Beck dan Burhanuddin Daya (red). ILmu Perbandiangan Agama di Indonesia dan Belanda (Jakarta: INIS, 1992), hlm. 208.

13 St. Sunardi, "Dialog: Cara Baru Beragama (Sumbangan Hans Kung bagi Dialog Antar agama)", dalam Abdurrahman Wahid, dkk, Dialog: Kritik dan Identitas Agama (Yogyakarta: Dian/Interfidei,1993), hlm. 78.

14 Ibid, hlm. 72.
}

390 JURNAL LISAN AL-HAL 
agama Ibrahimi (Abrahamic religions) atau hal-hal lain yang bersifat teologis. Dialog teologis ini misalnya; berupa perbincangan tentang keesaan Tuhan, otentisitas kitab suci, keabsahan seorang Nabi atau Rasul. Perbincangan tentang Tuhan adalah salah satu aspek yang paling sentral dalam agama manapun. ${ }^{15}$

Dialog teologis ini terjadi pada umat intra-agama, umat antar agama atau umat beragama, bahkan umat tidak beragama. Di dalam umat Islam misalnya; pernah ada pengalaman yang sangat seru dan memuncak dalam wilayah kalam (teologi), sehingga muncul tuduhan kafir, munafik, murtad dari satu kelompok kepada kelompok lainnya.

Umat Nasrani juga mengalami hal yang sama dengan munculnya Kristen Protestan, Hindhu, Budha dan lain sebagainya. Dalam teologis ini, para pemuka agama saling memberi informasi tentang keyakinan, kepercayaan dan amalan-amalan agama mereka, dan berusaha saling pengertian. ${ }^{16}$ Selain itu juga, dialog teologis adalah dialog yang membicarakan warisan-warisan keagamaan dengan nilai-nilainya agar dapat memahami dengan lebih dalam dan menghargai lebih luas. ${ }^{17}$

\section{Dialog Etis}

Pada tingkat etis dialog antar umat beragama membicarakan halhal yang bersifat moralitas dan etis yang harus dilakukan oleh siapapun pemeluk agama dan orang yang tidak beragama. Manusia sesungguhnya memiliki nasib yang sama sebagai manusia yang perlu hidup, makan serta memenuhi kebutuhan-kebutuhan yang ada. Oleh karena itu, etika universal atau moralitas universal dibutuhkan oleh manusia, etika universal ini antara lain adalah; hak asasi manusia, kebebasan, keadilan dan perdamaian. Ini semua diperlukan untuk membangun perdamaian, keharmonisan dan kesejahteraan hidup bersama. ${ }^{18}$

15 Azyumardi Azra, Bingkai Teologi Kerukunan Hidup Antar Umat Beragama : Perspektif Islam, dalam Sudjangi (peny.), Bingkai Teologi Kerukunan Hidup Antar Umat Beragama di Indonesia, (Jakarta : Balitbang Depag RI, 1996/1997), hlm. 12.

${ }^{16}$ A. Mukti Ali, Ilmu Perbandingan Agama, (Bandung: Mizan, 1998), hlm. 211.

17 Th. Sumartana dkk, Dialog: Kritik \& Identitas Agamai, (Yogyakarta : Institut DIAN/Intervidei, 2004), hlm. 17.

18 Bassam Tibi , Moralitas Internasional Sebagai Landasan Lintas Budaya, dalam M. Nasir Tamara dan Elza Pelda Taher (ed.), Agama dan Dialog Antar Peradaban, (Jakarta : Yayasan Paramadina, 1996), hlm. 163-164. 


\section{Dialog Empiris}

Pada tingkat empiris dialog antar agama tidak hanya bergerak dalam datataran pengetahuan mengenai agama lain, akan tetapi juga dalam tataran pengalaman dan keterlibatan iman yang mendalam. Dengan kata lain adalah pertemuan antara iman dengan iman. ${ }^{19}$ Ada yang mengatakan bahwa dialog ini merupakan dialog tinggi, suatu dialog yang memajukan panghayatan nilai-nilai rohani yang mendalam. Pada dialog inilah masing-masing berbagai pengalaman doa, kontemplasi, meditasi dan lebih dalam lagi yaitu pengalaman mistik. Dalam dialog pengalaman ini, para partisipan dialog diberi kesempatan untuk membagikan pengalaman-pengalaman keagamaan mereka yang berakar pada tradisitradisi agama masing-masing. ${ }^{20}$

\section{Prinsip Dasar Dialog}

Terdapat beberapa prinsip dalam dialogis yaitu: 1) Dialog antaragama harus merupakan suatu proyek dua pihak; internal masyarakat satu agama atau antar-msyarakat penganut agama yang berbeda; 2) Setiap peserta dialog harus mengikuti dialog dengan kejujuran, ketulusan yang sungguh-sungguh, dan sebaliknya dia juga harus yakin dan percaya bahwa mitra dialognya mempunyai ketulusan dan kesungguhan yang seperti dirinya; 3) Setiap peserta dialog harus mendefinisikan dirinya sendiri. Misalnya hanya orang Kristen lah umpamanya, yang dapat tepat menjelaskan apa artinya menjadi seorang Kristen. Orang lain hanya dapat mendeskripsikan apa yang dapat dilihatnya dari luar; 4) Peserta dialog harus mempunyai tujuan untuk mempelajari perubahan, perkembangan persepsi dan pengertian tentang realitas, kemudian berbuat menurut apa yang sesungguhnya diyakini; 5) Setiap peserta dialog harus mengikuti dialog tanpa asumsi-asumsi yang kukuh dan tergesa-gesa mengenai problem yang tidak bisa disetujui; 6) Dialog hanya bisa dilakukan di antara pihak-pihak yang setara. Umpamanya, kalau Hindu dianggap atau di nilai inferior oleh Kristen, maka dialog di antara kedua belah pihak akan tidak terlaksana; 7) Dialog harus dilaksanakan atas dasar saling percaya; 8) Peserta dialog antaragama, minimal harus bersifat kritis, taat beragama dan bisa berbuat baik terhadap umat agama lain; 9) Setiap peserta, akhirnya harus mencoba mengalami agama mitra dialog dari dalam. Artinya melihat setiap agama bukan hanya sebatas apa yang ada dalam logika mereka. Namun lebih dari

19 Ibid, hlm. 24 .

20 Th. Sumartana dkk, Ibid, hlm. 17.

$392 \mid$ JURNAL LISAN AL-HAL 
itu, harus mampu bisa merasakan dalam lubuk hati yang mendalam, baik secara bersama-sama atau perorangan; dan 10) Dalam dialog antaragama, tidak boleh membandingkan idealismenya dengan praktek patner dialognya. Yang perlu dilakukan adalah membandingkan yang se-ideal atau praktek dengan praktek lainnya. ${ }^{21}$

\section{Model-Model Dialog Antar Agama}

Menurut Azyumardi Azra, ada beberapa model dialog antar umat beragama (tripologi), yaitu;

Pertama, Dialog parlementer (parliamentary dialogue), yakni dialog yang melibatkan ratusan peserta, seperti dialog World's Parliament of Religions pada tahun 1873 di Chicago, dan dialog-dialog yang pernah diselenggarakan oleh World Conference on Religion and Peace (WCRP) pada dekade 1980-an dan 1990-an.

Kedua, Dialog kelembagaan (Institutional Dialogue), yakni dialog diantara wakil-wakil institusional berbagai organisasi agama. Dialog kelembagaan ini sering dilakukan untuk membicarakan masalah-masalah mendesak yang dihadapi umat beragama yang berbeda. Dialog seperti ini biasanya melibatkan majelis-majelis agama yang diakui pemerintah seperti Majelis Ulama Indonesia (MUI), Persatuan Gereja Indonesia (PGI), Konferensi Waligereja Indonesia (KWI), Parisada Hindu Darmadan Perwalian Umat Budha Indonesia (WALUBI).

Ketiga, Dialog teologi (theological dialogue). Dialog ini mencakup pertemuan-pertemuan reguler maupun tidak, untuk membahas persoalanpersoalan teologis dan filosofis. Dialog teologi pada umumnya diselenggarakan kalangan intelektual atau organisasi-organisasi yang dibentuk untuk mengembangkan dialog antar agama, seperti interfidei, paramadina, LKiS, LP3M, MADIA, dan lain-lain.

Keempat, Dialog dalam masyarakat (dialogue in community), dialog kehidupan (dialogue of live), dialog seperti ini pada umumnya berkonsentrasi pada penyelesaian "hal-hal praktis dan aktual" dalam kehidupan yang menjadi perhatian bersama dan berbangsa dan bernegara. Dialog dalam kategori ini biasanya diselenggarakan kelompokkelompok kajian dan LSM atau NGO.

Kelima, Dialog kerohanian (spritual dialogue), yaitu dialog yang bertujuan untuk menyuburkan dan memperdalam kehidupan spiritual

21 Burhanuddin daya, Agama Dialogis; Merenda Dialektika Idealitas dan Realita Hubungan antar Agama, (Yogyakarta : Mataram-Minang Lintas Budaya, 2004), hlm. 7172. 
diantara berbagai agama. ${ }^{22}$

\section{Dialog Antar Umat Beragama}

Dialog merupakan hal yang harus dikembangkan mengingat manusia senantiasa berada dalam proses perkembangan yang berlangsung terus-menerus tiada henti. Agama sebagai wahana pencarian manusia akan kebenaran karenanya juga terus-menerus berkembang mengikuti perkembangan peradaban manusia. ${ }^{23}$ Hal penting yang perlu diperhatikan dalam dialog menurut Hans Kung adalah bahwa setiap orang beragama harus membuktikan keimanannya masing-masing terlepas dari semua perbedaan yang ada. Misalnya orang Kristen dan umat Islam harus bertanggung jawab terhadap Tuhan dan melayani masyarakat manusia dengan penuh penghormatan satu sama lain. ${ }^{25}$

Ilmu perbandingan agama dan pemahaman terhadap agama orang lain merupakan prasyarat untuk melakukan dialog antar agama, karena tanpa ini dialog mustahil sesuai dengan yang diingikan. Ilmu perbandingan agama dipergunakan untuk memperlancar dialog, dan dialog antar agama sendiri merupakan media untuk memahami agama lain secara benar dan komprehensif. Dialog antar umat beragama yang benar dapat menimbulkan pemahaman dan pencerahan kepada umat dalam wadah kerukunan hidup antar umat beragama. Dalam dialog ini diperlukan sikap saling terbuka antar pemeluk agama yang berdialog.

Menganggap agama yang dipeluk adalah agama yang paling benar bukanlah anggapan yang salah, bahkan yakin bahwa agama yang ia peluk adalah agama yang paling benar, dan orang lain pun dipersilahkan untuk meyakini agama yang ia peluk adalah agama yang paling benar pula. Namun malapetaka akan timbul apabila orang yang yakin agama yang ia peluk adalah agama yang paling benar, lalu beranggapan karena itu orang lain harus ikut ia untuk memeluk agama yang ia peluk. ${ }^{28}$

${ }^{22}$ Azyumardi Azra, Konteks Berteologi di Indonesia: Pengalaman Islam (Jakarta: Paramadina, 1999), hlm. 63-64. Sedangkan menurut Burhanuddin Daya; Dialog Kehidupan, dialog perbuatan, dialog kerukuan, dialog sharing (pengalaman agama), dialog kerja sosial, dialog antar monastik, dialog doa bersama, dialog teologis, interfaith dialogue, dialog terbuka, dialog tanpa kekerasan dan dialog aksi. Ibid, hlm. 39

${ }^{23}$ Ahmad Wahib, Pergolakan Pemikiran Islam : Catatan Ahmad Wahib, eds. Djohan Effendi dan Ismed Natsir, (Jakarta : LP3ES, 1988), hlm. 71,

25 Hans Kung, "Sebuah Model Dialog Kristen-Islam" dalam Jurnal Paramadina (Jakarta, Paramadina Juli-Desember, 1998), hlm. 32 ,

28 Ibid, hlm. 67-68,

$394 \mid$ JURNAL LISAN AL-HAL 
Dialog harus diakui sebagai cara yang paling penting untuk membudayakan kehidupan rukun dan harmonis diantara seluruh umat beragama, yang sekarang berada dalam globalisasi dan pluralitas yang heterogen. Agama harus diahayati dalam semangat dialog, baik dialog vertikal (antara individu dengan Tuhannya) maupun dialog horizontal (antar sesama manusia). Dialog vertikal akan membuahkan kehidupan yang suci, indah dan jauh dari kesengsaraan, sedangkan dialog horizontal akan menciptakan ketertiban, keserasian, kedamaian, kerjasama dan lain sebagainya. ${ }^{24}$ Dialog antar umat beragama akan membawa pemeluknya untuk tumbuh dalam kepercayaannya sendiri manakala ia berhadapan dengan orang yang memiliki kepercayaan berbeda, seringkali kebenaran itu lebih baik disadari, lebih jauh dipelajari, diperdalam, dihargai, dipahami dan dihayati, manakala berhadapan dengan pandanganpandangan lain. Dialog antar umat beragama membantu untuk meningkatkan kerjasama antar pemeluk-pemeluknya, hingga dengan demikian secara bersama-sama dapat menegakkan kemanusiaan, keadilan, perdamaian, dan persaudaraan. ${ }^{25}$

\section{E. Faktor Penghambat dan Pendorong Dialog}

Beberapa faktor pendukung berkembangnya dialog antar umat beragama antara lain: 1) Aspek ideologi, Pancasila sebagai dasar negara. Secara ideologis, Pancasila yang memuat nilai-nilai ketuhanan, kemanusiaan, persatuan, demokrasi dan keadilan, sangat mendorong munculnya budaya dialog di kalangan masyarakat Indonesia; 2) Sistem politik yang demokratis. Sistem dan budaya politik yang demokratis sangat mendukung perkembangan budaya dialog, karena demokrasi mengasumsikan penyelesaian konflik tanpa kekerasan; 3) Nilai ajaran agama. Pada dasarnya semua agama mengajarkan pada umatnya saling menyayangi satu sama lain, tanpa membedakan asal-usulnya. Sehingga tidak dibenarkan menghadapi masalah dengan menggunakan kekerasan. Islam misalnya, sangat mengutamakan musyawarah dalam menyelesaikan masalah; dan 4) Budaya lokal. Bangsa Indonesia kaya akan tradisi dan budaya lokal. Setiap masyarakat mempunyai adat atau mekanisme tersendiri dalam menyelesaikan segala persoalan yang mereka hadapi. Budaya lokal ini akan menjadi modal yang sangat berharga untuk mengembangkan dialog, khususnya dialog antar umat beragama di

24 Ibid, hlm. 70-71,

${ }^{25}$ Ja'far Suhermanto, Filsafat Perennial dan Titik Temu Agama-agama, (Surabaya : Elkaf, 2007), hlm. 116, 
masyarakat, jika ia dijaga, dikembangkan, diselesaikan dengan konteks perubahan zaman.

Adapun faktor penghambat dialog antar umat beragama diantaranya: 1) Gerakan misi dan dakwah yang masih menempatkan kuantitas umat sebagai tujuan utama. Misalnya agama Kristen dan Islam, mereka sama-sama mempunyai tugas untuk mengajak seluruh umat manusia agar mengikuti ajarannya; 2) Kecenderungan stereotip dan parasangka terhadap agama lain. ${ }^{26}$ Faktor ini menjadi penghalang dialog antar umat beragama yang sulit diatasi. ${ }^{27}$ 3) Klaim kebenaran (truth claim) mengakar kuat pada masyarakat menjadikan agama mudah diseret ke ranah konflik. Klaim kebenaran suatu agama menggiring pada berkembangnya gerakan fundamentalisme dan eksklusivisme. ${ }^{28}$ Dan 4) Minimnya pengetahuan dan internalisasi nilai-nilai agama sendiri dan kurangnya pengetahuan tentang agama lain.

\section{F. Menggerakkan Dialog dari Bawah}

Pertama, Interfidei (Institute for interfaith dialogue in Indonesia), yang didirikan pada 1991 di Yogyakarta. ${ }^{29}$ Menurut konsep Interfidei, dialog mengandung konflik inheren pada hubungan antar manusia, sekaligus menjanjikan sebuah akhir yang lebih dewasa untuk menghadapi dan menyelesaikan konflik. Interfidei menganggap penting posisi individu sebagai umat beriman sehingga keterlibatan setiap individu dalam Interfidie dipandang tidak mewakili golongan tertentu secara struktural, melainkan sebagai individu-individu yang memiliki minat terhadap dialog antar agama. ${ }^{30}$ Kegiatan Interfidei dibagi beberapa bidang, diantaranya; 1) bidang pendidikan yang menggunakan metode semiloka dan lokakarya tentang studi agama-agama serta studi agama dan masyarakat. Studi agama-agama lebih menonjolkan kajian (teologis) relasi antar agama, sedangkan studi agama dan masyarakat lebih menekankan peran agama-

${ }^{26}$ Josef Van Ess, "Islam dan Barat dalam Dialog”, dalam Nurcholish Madjid, dkk., Agama dan Dialog Antar Peradaban (Jakarta: Paramadina, 1996), hlm. 90,

${ }^{27}$ Pengantar, dalam Abdurrahman Wahid, dkk, Dialog: Kritik dan Identitas Agama, (Yogyakarta : Dian/Interfidei,1993), hlm. 88,

${ }^{28}$ Johan Meuleman, "Sikap Islam Terhadap Perkembangan Kontemporer”, dalam A. Mukti Ali, dkk, Agama dalam Pergumulan Masyarakat Dunia (Yogyakarta: Tiara Wacana, 1997), hlm. 28,

29 Th. Sumartana, Sejarah Singkat, Visi dan Misi DIAN/Intervidei, Newsletter Intervidei, Edisi Khusus, 2001, hlm. 5,

30 JB. Banawiratma dan Zainal Abidin Bagir etc., Dialog Antar Umat Beragama; Gagasan dan Praktik di Indonesiai, (Jakrta : Mizan Publika Anggota IKPI, 2010), hlm. 131132 ,

$396 \mid$ JURNAL LISAN AL-HAL 
agama di dalam hubungannya dengan problem kontekstual masyarakat; 2) bidang penelitian yang belakangan ini memfokuskan pada penelitian partisipatif pendidikan agama di sekolah umum di Yogyakarta, dari Sekolah Dasar (SD) sampai sekolah lanjutan; 3) Interfidei mengembangkan kegiatan diseputar diskusi rutin dan seminar sebagai bagian dari usaha untuk mendesiminasi wacana kemajemukan; 4) Bidang penerbitan, dengan menerbitkan secara rutin newletter dan buku-buku, Interfidei bertujuan untuk membangun opini publik, bahwa pluralitas merupakan potensi dan kekayaan bangsa yang dapat membawa bangsa ini pada kemajemukan yang bermartabat. ${ }^{31}$

Kedua, Lembaga Kajian Islam dan Sosial (LKiS) muncul dari kelompok kajian di Yogyakarta pada 1990-an. Aktifis yang muncul dalam lingkaran ini pada umumnya memiliki latar pendidikan pesantren. Bagi mereka, pesantren dipahami sebuah sub-kultur yang kemudian mempengaruhi model gerakan mereka. Kelompok tersebut merasa lahir dari perkembangan pemikiran dan gerakan Islam, disatu pihak, dan kekuasaan Orde Baru di pihak lain. Dipihak gerakan Islam, muncul kecenderungan stagnasi dan konservatisme yang berlebihan. Dipihak kekuasaan Orde Baru, muncul kesadaran dan usaha nyata untuk memanfaatkan Islam sebagai alat pendukung dan pelestari kekuasaan represif. Dari sinilah muncul kesadaran dari kelompok kecil ini untuk meretas pengenalan wacana Islam kritis dan sekaligus mendorong pentingnya gerakan keterbukaan dan demokratisasi bersama masyarakat. ${ }^{32}$ Meski tidak secara langsung fokus pada kegiatan dialog antar agama, LKiS merupakan kantong pergerakan yang sangat kuat dalam mengusung wacana dan transformasi paham Islam dan pluralisme. Dalam wacana pluralisme LKiS menggeser wacana dialog dalam bingkai kerukunan ke dialog dalam bingkai demokrasi. Menyebarluaskan gagasan Islam yang transformatif, toleran yang bersifat keindonesiaan. ${ }^{33}$ Kegiatan yang dilakukan oleh LKiS diantaranya; 1) Penerbitan bulettin Al-Ikhtilaf, media penyebaran nilai-nilai transformatif dan toleran dalam Islam; 2) belajar bersama, sebagai wadah memperbincangkan gagasan-gagasan transformatif dan toleran dalam Islam; 3) Penerbitan buku-buku yang mengandung nilai-nilai Islam yang transformatif dan toleran; dan 4) Kelas dialog antar agama yang di berinama sekolah pluralisme, dan lain sebagainya.

31 Ibid, hlm. 135-136,

32 JB. Banawiratma, Ibid, hlm. 141-142,

33 Ibid, hlm. 146, 
Ketiga, Lembaga Antar-Iman Maluku untuk Kemanusiaan (ELALEM) yang lahir di Maluku dalam kontek masyarakat Maluku pasca konflik. Para penggagas lembaga itu merasa malu secara moral dan marah melihat kondisi Maluku, yang kemudian dikenal sebagai wilayah hot spot konflik sosial keagamaan. Gagasan untuk mendirikan ELALEM muncul sejak akhir 2000 dan secara resmi berdiri pada 2003. Keprihatinan mereka diejewantahkan dengan mendirikan ELALEM yang membawa citacita menjadi lembaga bersama antar umat beragama sebagai pusat pembelajaran pluralitas dan juga diharapkan menjadi wadah terciptanya interaksi yang berkesinambungan antar pemeluk agama pada setiap segmen masyarakat, sehingga tercapai sikap saling memahami, percaya dan menerima, demi proses pemulihan masyarakat setelah mengalami konflik. Kegiatan yang dilakukan oleh ELALEM terkait dialog antar umat beragama diantaranya; Pertama, dialog publik, peserta dari berbagai kalangan dan tokoh lintas agama tentang isu-isu kontemporer konflik, kekerasan dan perdamaian, seni dan budaya, media dan jurnalisme damai, pendidikan serta pluralisme. Kedua, dakwah perdamaian, untuk menyebarkan gagasan perdamaian dan mengurai konflik yang dilakukan dengan cara berkeliling kepelosok-pelosok Maluku. Ketiga, bimbingan konseling dan penyembuhan trauma bekerjasama dengan Crisis Center Gereja Kristen Maluku dan Yayasan Kasih Mandiri (Katolik), dan juga bekerja sama dengan Interfidei dengan membahas dua hal sekaligus, yakni kajian literatur keagamaan tentang kemajemukan agama, dan kajian tentang hubungan agama-agama dan budaya lokal.

\section{G. Simpulan}

Dialog harus dipahami sebagai roh kehidupan dan selalu terusmenerus dilakukan. Dalam melakukan dialog antar umat beragama apapun bentuknya diperlukan adanya sikap saling terbuka, saling menghormati, dan kesediaan untuk mendengarkan yang lain. Bahkan yang perlu disadari dalam dialog antar umat beragama bukan hanya bertujuan untuk hidup bersama secara damai (atau dalam jargon Orde Baru, "secara rukun dan toleran"), dengan cara membiarkan pemeluk agama lain 'ada' (ko-eksistensi), melainkan juga berpartisipasi secara aktif meng-ada-kan pemeluk agama lain itu (pro-eksistensi). Selain itu, yang perlu ditekankan dalam dialog antar umat beragama adalah mencari titik temu (kalimatun sawa') bukan titik beda, karena masing-masing agama mempunyai karakteristik yang sangat unik dan sangat komplek. Demi mensukseskan dialog antar umat beragama maka pemahaman terhadap agama-agama lain tidak hanya diperlukan oleh para elit agama, tetapi harus merambah

398 JURNAL LISAN AL-HAL 
kepada masyarakat lapisan terbawah atau masyarakat awam (akar rumput) yang bergesekan langsung dengan para pemeluk agama-agama lain dalam hidup kesehariannya.

Sepakat atau tidak, agama datang untuk menciptakan kedamaian dan kerukunan hidup manusia berlandaskan nilai-nilai kebenaran dan keadilan nan Ilahiyah. Tak satupun agama yang hadir ke dunia ini untuk membentuk manusia-manusia brutal dan bringas. Justru dalam agamalah manusia menemukan prinsip dasar untuk saling mengasihi, menyayangi dan mencintai antar sesama manusia. Jika umat beragama mengabaikan prinsip dasar tersebut atau menjadikan agama sebagai legitimasi terhadap tindak kekerasan dan kekejaman terhadap sesama manusia, itu berarti telah mengingkari nilai-nilai paling pokok ajaran agama itu sendiri. Yakni, rahmatan lil alamin atau kasih sayang bagi alam semesta.

\section{DAFTAR PUSTAKA}

Ali A. Mukti, Ilmu Perbandingan Agama, Bandung, Mizan, 1998.

dkk, Agama dalam Pergumulan Masyarakat Dunia, Yogyakarta, Tiara wacana, 1997.

Azra Azyumardi, Bingkai Teologi Kerukunan Hidup Antar Umat Beragama : Perspektif Islam, dalam Sudjangi (peny.), Bingkai Teologi Kerukunan Hidup Antar Umat Beragama di Indonesia, Jakarta, Balitbang Depag RI, 1996/1997.

Konteks Berteologi di Indonesia : Pengalaman Islam, Jakarta, Paramadina, 1999.

Burhanuddin Daya dan Herman Leonard Beck (red). Ilmu Perbandiangan Agama di Indonesia dan Belanda, Jakarta, INIS, 1992.

Coward Harold, Pluralisme dan Tantangan Agama-agama, Yogyakarta, Kanisius, 1989.

Daya Burhanuddin, Agama Dialogis; Merenda Dialektika Idealitas dan Realita Hubungan antar Agama, Yogyakarta, Mataram-Minang Lintas Budaya, 2004.

Elza Pelda Taher dan M. Nasir Tamara (ed.), Agama dan Dialog Antar Peradaban, Jakarta, Yayasan Paramadina, 1996.

Ja'far Suhermanto, Filsafat Perennial dan Titik Temu Agama-agama, Surabaya, Elkaf, 2007.

Madjid Nurcholish dkk., Agama dan Dialog Antar Peradaban, Jakarta, Paramadina, 1996.

Komaruddin Hidayat dan Ahmad Gaus AF (ed), Passing Over : Melintasi Batas Agama, Jakarta, Gramedia dan Paramadina, 1998. 
Kung Hans, "Sebuah Model Dialog Kristen-Islam" dalam Jurnal Paramadina, Jakarta, Juli-Desember, 1998.

Wahid Abdurrahman dkk., Dialog: Kritik dan Identitas Agama, Yogyakarta, Dian/Interfidei, 1993.

Sudarto H., Konflik Islam Kristen, Semarang, Pustaka Rizki Putra, 2001.

Sumartana Th. dkk, Pluralisme, Konflik dan Pendidikan Agama, Yogyakarta, Pustaka Pelajar, 2001.

Sejarah Singkat, Visi dan Misi DIAN/Intervidei, Newsletter Intervidei, Edisi Khusus, 2001.

dkk, Dialog: Kritik \& Identitas Agamai, Yogyakarta, Institut DIAN/Intervidei, 2004.

Tracy David, Plurality and Ambiguity, Hermeneutic, Religion, Hope, University of Chicago Press, 1987.

Wahib Ahmad, Pergolakan Pemikiran Islam : Catatan Ahmad Wahib, eds. Djohan Effendi dan Ismed Natsir, Jakarta, LP3ES, 1988.

Zainal Abidin Bagir dan JB. Banawiratma etc., Dialog Antar Umat Beragama; Gagasan dan Praktik di Indonesiai, Jakrta, Mizan Publika Anggota IKPI, 2010.

400 JURNAL LISAN AL-HAL 